\title{
THE INFLUENCE OF VARIABILITY OF WATER RESOURCES IN LOWLAND FORESTS ON SELECTED PARAMETERS DESCRIBING THE CONDITION OF TREES
}

\author{
JAN TYSZKA, ANDRZEJ STOLAREK, EWA FRONCZAK \\ Division of Forest Ecology, Forest Research Institute \\ 05-090 Sękocin Stary, Braci Leśnej 3 str., Poland \\ j.tyszka@ibles.waw.pl, a.stolarek@ibles.waw.pl, e.fronczak@ibles.waw.pl
}

\begin{abstract}
The influence of water conditions on the condition and growth of tree stands has been analysed in the context of the climatic and hydrological functions forest plays. Long observational series obtained for precipitation, outflow and depths below the surface of the water table have been put together with measured increases in the breastheight diameters of Scots pines and the severity of crown defoliation observable in selected tree species growing on the Polish Lowland, in order to determine the overall scope to the reaction stand condition manifests in the face of ongoing variability of water conditions within forest. An overall improvement in the condition of stands over the last 20 years does not disguise several-year cyclicity to changes capable of shaping the situation, i.a. departures from long-term mean values for precipitation totals and groundwater levels. The condition of stands is seen to worsen in both dry and wet years. Analysis of the degree to which pine, spruce and broadleaved stands experience defoliation points to spruce stands responding most to extreme hydro-climatic conditions. Extreme situations as regards water resources were seen to involve a response over two-year time intervals in the case of coniferous stands. Unsurprisingly, optimal growing-season (June-September) precipitation totals correspond with long-term average figures, while being slightly higher for spruce (at $384 \mathrm{~mm}$ ), than for Scots pine or broadleaved species $(375 \mathrm{~mm}$ ).

The relationships reported gain confirmation in analysis of periodic change in breastheight diameter increments characterising Scots pines, whose growth is seen to depend
\end{abstract}


closely, not only on precipitation, but also above all on the depth of the water table in the summer half-year. Optimal depths of the water table proved to be different, being around $20 \mathrm{~cm}$ below ground in the case of marshy coniferous forest, $80 \mathrm{~cm}$ in wet habitats, and $135 \mathrm{~cm}$ in fresh habitats. Depending on the possibilities for water to soak into the rooting zone of trees there were even twofold differences in measured growth increments in Scots pine (as the dominant species in Poland's lowland habitats).

The maintenance of stable water conditions (as the most variable environmental factor in forest) should be an overriding aim of management activity in this habitat. When account is taken of the influence of the state of water resources on biomass production, and then on the intensity of evapotranspiration and the absorption of carbon dioxide from the atmosphere, it is seen how important it is to achieve improvements in water conditions in forests, as such an important factor in combating climate change.

KEY WORDS: variability to water resources, condition of tree stands.

\section{INTRODUCTION}

In a period of intensifying change to the water relations that govern the functioning of forests, it becomes increasingly important to understand the interrelationships between forest and hydrological parameters. This in particular concerns the influence of the availability of water on the state of tree-stands, as well as the reverse relationships by which forest is able to influence water resources. In recent decades, periodic changes involving climatic variables, combined with current trends towards an increase in temperature and frequent short-lived weather anomalies, have been particular causes of change involving precipitation.

Development of forest is obviously not merely affected by changes in temperature. Indeed, a far more significant factor is a lack of equilibrium between changes in temperature and in precipitation. Stands' use of water via evapotranspiration is proportional to the increase in the biomass of the trees present, and needs to be compensated for by precipitation, but also an adjustment in the distribution of rainfall that is in line with the periodic change to the demand for water that stands manifest. On the Polish Lowland, precipitation totals are low, but nevertheless favourable as regards distribution through the year, since rainfall in the summer half-year accounts for around $62 \%$ of annual totals.

The demand for water in the (April-October) growing season follows an individualised course specific to the kind of land cover (Kędziora, Ryszkowski 1999). In a forest-covered drainage basin it is dependent on the fertility of the habitat as well as the degree of stand diversity in terms of species composition and age (Suliński 1990). The depth of rooting of trees and the possibility for water to soak into wet habitats affect a forest's opportunities to take advantage of groundwater resources (Hendricks and Hansen 1962). Thus, a study of climatic conditions and their significance for forest-ecosystem processes needs to take account of both dry years with major deficits of precipitation in the summer half-year and wet years in which there is an excess. 
The work described here represented an attempt to link incremental increases in biomass and changes in the condition of trees in given habitats and forest drainage basins with periodic fluctuations in the level of water resources. More specifically, its analysis addressed:

- the influence of the availability of groundwater resources on annual and multiannual growth in girth among Scots pine and Norway spruce trees, as expressed by radial increments in cross-sections $1.3 \mathrm{~m}$ above the ground (i.e. breast-height diameters),

- the relationship between the rate of increase in breast-height diameters among pines and data for annual precipitation or precipitation in the summer half-year,

- the influence of growing-season rainfall on the condition of trees, as evidenced by the degree of damage and discolouration exhibited by foliage (i.e. defoliation).

Obtained results were expected to permit the more accurate determination of the real causes of periodic, relatively localised, declines in the condition of stands, not least with a view to these being combated effectively in practice. A further intended aim of the research was to arrive at a relatively accurate assessment of the sensitivity of tree stands with different species to water-resource disturbances in given habitats.

\section{RESEARCH METHODOLOGY AND SCOPE}

With a view to interpreting the influence of changing water relations in a forest on the persistence of stand functioning, use was made of long series of measurements of hydrological parameters, as well as characterisations of the condition of trees representing one element to the statutory activity of Poland's Forest Research Institute. The measurements concern water resources in terms of precipitation, runoff/flow and the level of groundwater, as well as the state of health of stands measured by reference to both defoliation and girth increases relating to breast-height diameters.

The units of time referred to in assessing changes in hydrological parameters were years or half-years, these allowing for analysis over longer periods - for which it proved possible to establish the uniform nature of relationships between different parameters. To determine the trend for changes in the depth of the water table below the surface, archival results from decade-long measurements were used, while consideration was also given to the level of response to amounts of precipitation recorded at nearby weather stations. The field measurements made and processed (for 28 small research basins within or in the immediate vicinity of larger forest complexes in north-eastern and central Poland (Fig. 1, Tab. 1) concerned 24-hour totals for precipitation and runoff which allow periodic and long-term change in water resources to be assessed.

The observation period considered reliable in determining mean hydrological parameters extended to 20 years (Byczkowski 1996). Directional trends to changes in annual (November-October) or summer half-year (May-October) precipitation totals were established, the years 1980-1992 being revealed as a period with a downward trend for runoff regarded as common to many basins and constituting an indicative surface measure of 
changes in available resources (Pierzgalaski, Tyszka 2005). The variability to precipitation in Poland post 1996 was interpreted using the results of measurements from 22 synoptic stations of Poland's Institute of Meteorology and Water Management. This allowed for the identification of years and (April-September) half-yearly growing seasons in which weather parameters displayed extreme values. Water - as the most evidently variable element to a tree's environment - was capable of being assessed in relation to these annual or half-yearly values, while also being characterised by long-term trends for:

- precipitation totals and variability $\mathrm{P}(\mathrm{mm})$, i.e. the most major component element in the water cycle;

- overall outflow/runoff and the variability thereto - $\mathrm{H}(\mathrm{mm})$, as a measure of changes in the water resources of forest habitats on the larger scale;

- the depths of occurrence and amplitudes of the water table $-\mathrm{h}(\mathrm{cm})$ - as measured in habitats typical for a given basin by reference to transects with boreholes established at right angles to each river. The shaping of the water table has been interpreted by reference to measurements from 18 research plots located beneath the tree canopy in the large forest complexes in Poland known as Puszcza Knyszyńska, Puszcza Białowieska (the Białowieża Primeval Forest), Puszcza Biała and the Janowskie Forests (as situated within the wider Puszcza Solska complex) - Figure 1.

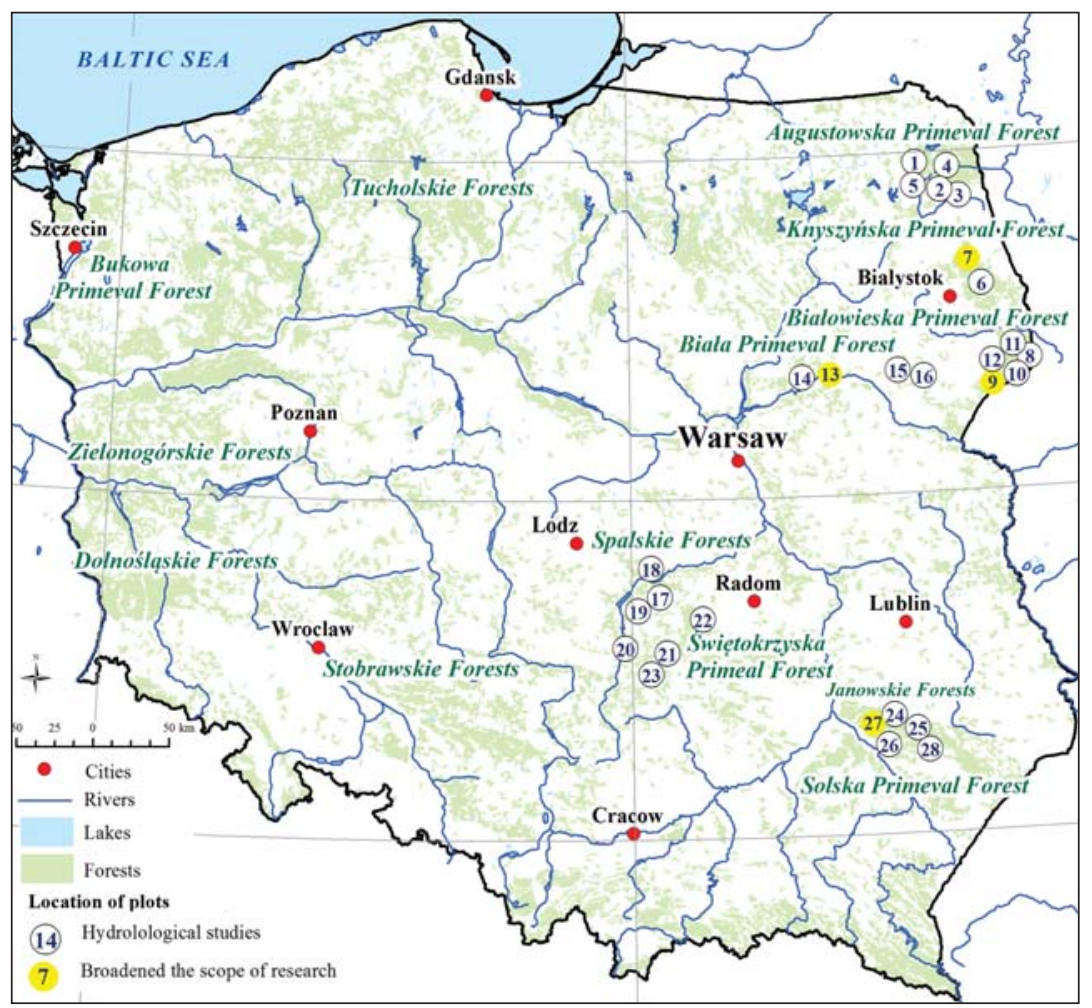

Figure 1. Locations of plots 
Table 1. Characteristics of the research plots

\begin{tabular}{|c|c|c|c|c|c|c|c|c|}
\hline No & River name & $\begin{array}{c}\text { Water gauge } \\
\text { profile }\end{array}$ & Forest areas & $\underset{\left(\mathbf{k m}^{2}\right)}{\mathrm{A}}$ & \begin{tabular}{|c|}
$\bar{h}$ \\
(m a.s.l.)
\end{tabular} & $\begin{array}{c}\bar{i} \\
(\%)\end{array}$ & $\begin{array}{c}\lambda \\
(\%)\end{array}$ & $\begin{array}{c}\bar{h}_{\mathrm{zw}} \\
\text { (m u.g.s.) }\end{array}$ \\
\hline 1 & $\begin{array}{l}\text { Kamienny } \\
\text { Bród }\end{array}$ & Augustów & \multirow{5}{*}{$\begin{array}{l}\text { Augustowska } \\
\text { Primeval } \\
\text { Forest }\end{array}$} & 85.7 & 158 & 2.9 & 7 & 5.2 \\
\hline 2 & Żeźwianka & Balinka & & 8.4 & 125 & 1.1 & 99 & 1.5 \\
\hline 3 & Jastrzębianka & Jastrzębna & & 75.5 & 125 & 1.4 & 81 & 2.2 \\
\hline 4 & Święty Jan & Sucha Rzeczka & & 16.0 & 135 & 0.7 & 99 & 3.0 \\
\hline 5 & Lebiedzianka & Lebiedzin & & 57.2 & 126 & 2.7 & 84 & 2.7 \\
\hline 6 & Woroniczanka & Woronicze & \multirow{2}{*}{$\begin{array}{l}\text { Knyszyńska } \\
\text { Primeval } \\
\text { Forest }\end{array}$} & 28.6 & 160 & 9.1 & 67 & 5.0 \\
\hline 7 & Jałówka & Polanki & & 47.1 & 175 & 8.0 & 76 & 5.5 \\
\hline 8 & Braszcza & Gruszki & \multirow{5}{*}{$\begin{array}{l}\text { Białowieska } \\
\text { Primeval } \\
\text { Forest }\end{array}$} & 33.0 & 156 & 4.4 & 75 & 1.5 \\
\hline 9 & Perebel & Topiło & & 21.6 & 164 & 4.9 & 66 & 2.0 \\
\hline 10 & Orłówka & BPN & & 18.3 & 161 & 5.9 & 100 & 2.2 \\
\hline 11 & Lutownia & Pogorzelce & & 64.2 & 165 & 9.9 & 93 & 2.1 \\
\hline 12 & Chwiszcza & Orzeszkowo & & 35.5 & 168 & 6.3 & 8 & 2.5 \\
\hline 13 & Turka & Brok & \multirow{4}{*}{$\begin{array}{l}\text { Biała } \\
\text { Primeval } \\
\text { Forest }\end{array}$} & 24.9 & 110 & 2.0 & 77 & 2.7 \\
\hline 14 & Tuchełka & Poręba Kocęby & & 82.4 & 105 & 2.0 & 64 & 2.7 \\
\hline 15 & Siennica & Koce Piskuły & & 55.4 & 140 & 3.2 & 41 & 2.2 \\
\hline 16 & Czarna & Puchały Stare & & 99.5 & 160 & 3.7 & 32 & 2.0 \\
\hline 17 & Słomianka & Antoniówka & \multirow{3}{*}{$\begin{array}{l}\text { Spalskie } \\
\text { Forests }\end{array}$} & 28.6 & 174 & 3.3 & 13 & 4.4 \\
\hline 18 & Olszynka & Liciążna & & 24.1 & 179 & 6.4 & 75 & 5.7 \\
\hline 19 & Młynówka & Nosalewice & & 18.4 & 229 & 7.9 & 69 & 6.3 \\
\hline 20 & Plebanka & Radoszyce & \multirow{4}{*}{$\begin{array}{l}\text { Świętokrzyska } \\
\text { Primeval } \\
\text { Forest }\end{array}$} & 32.2 & 278 & 12.4 & 21 & 2.0 \\
\hline 21 & Jaślanka & Osełków & & 21.3 & 359 & 38.1 & 51 & 2.0 \\
\hline 22 & Jabłonica & Rusinów & & 31.6 & 294 & 36.8 & 68 & 2.5 \\
\hline 23 & Łososinka & Wólka Klucka & & 24.4 & 283 & 25.4 & 10 & 1.8 \\
\hline 24 & Branew & Flisy & \multirow{5}{*}{$\begin{array}{l}\text { Janowskie } \\
\text { Forests }\end{array}$} & 50.5 & 250 & 7.4 & 22 & 4.5 \\
\hline 25 & Królówka & Biłgoraj & & 21.7 & 231 & 9.0 & 81 & 3.0 \\
\hline 26 & Kurzynka & Huta Stara & & 39.1 & 205 & 4.0 & 65 & 1.8 \\
\hline 27 & Czartusowa & Szklarnia & & 12.9 & 203 & 8.9 & 93 & 2.6 \\
\hline 28 & Rakowa & Władysławów & & 81.2 & 240 & 11.5 & 28 & 5.5 \\
\hline
\end{tabular}

Explanation of symbols:

$\mathrm{A}\left(\mathrm{km}^{2}\right)$ - catchment area;

$\bar{h}$ (m a.s.1.) - altitude of the catchment area;

$\bar{i}(\%)$ - average slope;

$\lambda(\%)$ - degree of forest cover ;

$\bar{h}_{\mathrm{zw}}$ (m u.g.s) - average depth of the groundwater table underground surface. Groundwater level measurements were carried out in cross-sections located in the catchment. 
The state of health of trees was assessed within the context of the damage monitoring of forests in Poland (Wawrzoniak 2013). Regular measurements were made from 1996 onwards on first-order permanent observation plots distributed across an 8x8 km grid, as well as 148 second-order plots (Manual... 2010). Particular attention was paid to estimates of the state of tree-crowns and the pigmentation of leaves in trees over 20 or 40 years old. This provided a basis for the identification of five defoliation classes, with further analyses being based around indicative values of $10 \%$ or less defoliation (class 0 - effectively healthy trees) and the more than $25 \%$ defoliation or die off characteristic of classes 2-4. Notwithstanding non-uniform measurement methods over time, it proved possible to obtain an approximate interpretation of the influence wet and dry years exert, as well as to relate the state of health of tree stands to cyclical variability of precipitation totals at synoptic stations of the Institute of Meteorology and Water Management. Account was taken of mean values for defoliation among specimens of the main species of coniferous tree (Scots pine and Norway spruce), as well as all broadleaved species (beech, oak, birch, alder, maple and so on) taken together.

Increments in the breast-height diameters of pine and spruce, i.e. species with distinct annual growth rings, were measured in some 10-20 trees growing around individual boreholes at which the level of the water table was measured. Annual radial growth of trees, as well as mean values for successive years, were determined in stands whose habitat conditions differed markedly. The indicative measure of the degree to which trees' demand for water was being met was the amplitude to water levels recorded in the summer halfyear, as related to habitat type, but also a forest's species and age structure.

The analysis of tree growth entailed the tracking of 10-year trends for changes in breast-height diameter. Under stable environmental conditions in which there are no external stimuli distorting annual increases in girth, this should be a steady process, with at-most minor fluctuations. Hence any long-term decrease or increase in rates of growth in girth should be taken to support hypotheses that environmental conditions are changing. Use was made of a method of forecasting increases in the girth of pines (Bruchwald et al. 1999), which takes precipitation totals into account. Forecasts of rates of increase in breast-height diameter $(T)$ are determined using values for age 100 years on the basis of the formula:

where:

$$
T=\frac{D}{E}
$$

$D$ - is the mean breast-height diameter (in $\mathrm{mm}$ ) of trees continuing to grow upwards, and hence in biosocial classes I or II after Kraft,

$E$ - is a standardised function for the increase in breast-height diameter described by models for the growth in the girth of trees at a height $1.3 \mathrm{~m}$ above the ground, as related to age (Bruchwald 1986, Bruchwald et al. 1999).

The adopted scope and methods for the collection and interpretation of multi-year input data allowed for the assessment of the relationships between selected hydrological and forest-related elements. 


\section{RESULTS}

\section{ASSESSMENT OF CHANGES IN FOREST WATER RESOURCES}

An objective evaluation of trends as regards forest water resources requires characterisation of at least the main components of the overall water balance. While its physical-geographical features and morphogenetic relief are rather uniform, the Polish Lowland nevertheless manifests differing climates, first and foremost in regard to precipitation totals (in the range $450-750 \mathrm{~mm}$ ). Mean annual air temperature varies across the more limited range $6.5-8.5^{\circ} \mathrm{C}$, and has been displaying an upward trend. Precipitation totals in the studied drainage basins were determined for annual and halfyear periods through the years 1966-2012. While the precipitation totals noted in different basins did differ, this was overlain by long-term directional change, as well as similar variability over periods up to several years long. The years 1966-1976 were characterised by an upward trend for summer rainfall, coinciding with a decline in annual precipitation totals. The years 1973-1992 in turn experienced declining precipitation totals for both the calendar year as a whole and the summer half-year, but these trends have since given way to a an overall re-increase in precipitation totals (Fig. 2).

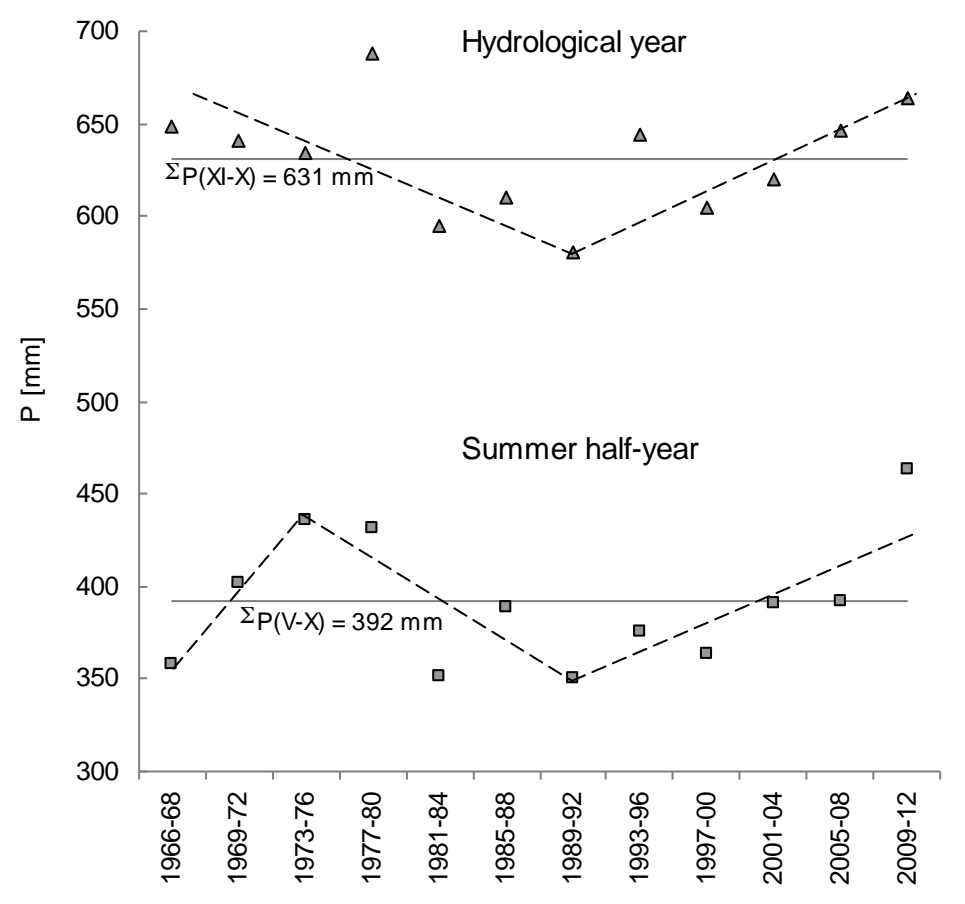

Sub-periods within the overall period 1966-2012

Figure 2. Long-term variability to the shaping of weighted mean totals for precipitation ( $\mathrm{P}$ in $\mathrm{mm}$ ) measured in lowland forest drainage basins of north-eastern and central Poland 
Torrential rain is seen to occur more frequently in periods with a mean annual air temperature above $7.5-8.0^{\circ} \mathrm{C}$, while the winter half-year is then characterised by increased precipitation, as well as a greater likelihood that this will fall as rain, as opposed to snow. Periodic variability in runoff as well as total runoff are both influenced (Tyszka 2008), this obviously also having at least an indirect effect on resources of groundwater.

An important role in any assessment of the water resources in forest ecosystems is played by research into habitats' capacity to retain water (Suliński 1990, 1993; Kosturkiewicz et al. 2002). While a greater thickness of the aeration layer in fresh habitats ensures long-term (multi-annual) stability of river flow, a greater presence of hydrogenic habitats is associated with intensive reactions when it comes to runoff and flow - i.e. to shortfalls in precipitation on the one hand, or to extreme cloudburst, downpour or meltwater phenomena on the other (Fig. 3).

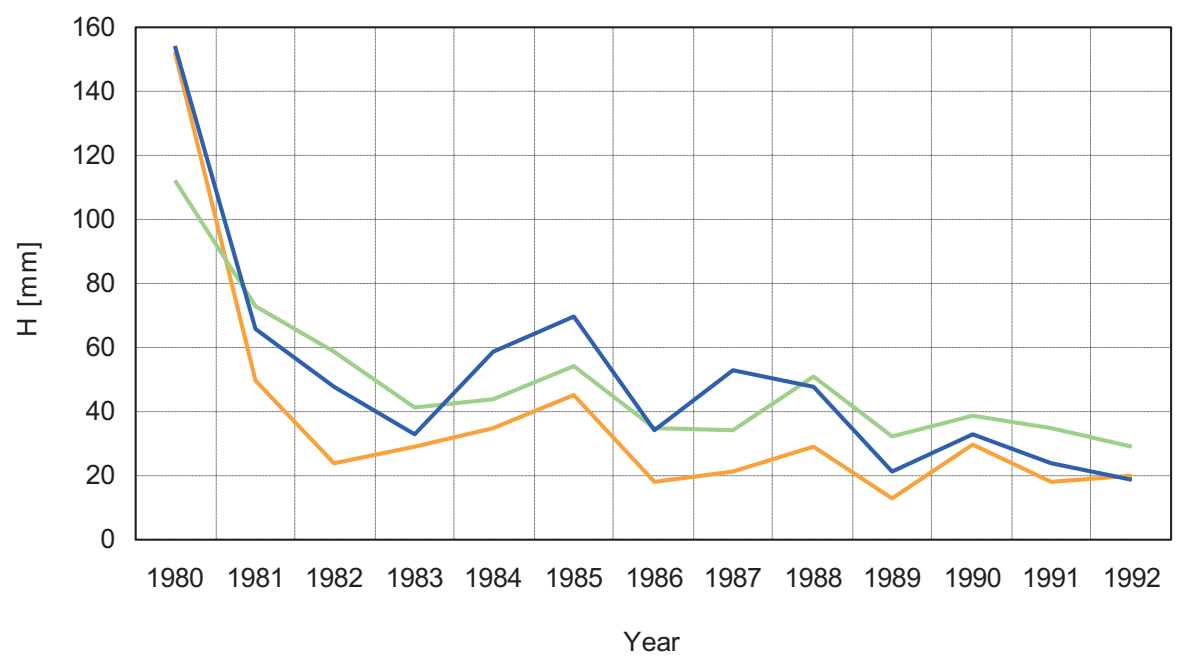

- Agricultural _ Forest - fresh habitats $\quad$ Forest - wet habitats

Figure 3. Influence of land-use conditions in the lowland basins analysed on the development of runoff in the summer half-years of the 1980-1992 period of progressing drought

While organic soils have favourable retention properties, these cannot compensate for the impact on runoff of groundwater located close to the surface. This is made clear by the data for the 1980-1992 period, which saw a preponderance of dry years. In the drainage basins studied, in which land-use is similar, declines in outflow during the summer half-year nevertheless followed courses that were by no means uniform. Forest-covered drainage basins with fresh habitats sustained overall increases in outflow as compared with those used agriculturally, as well as evened-out courses to the flows observed. In turn, in forest basins where wet habitats prevailed, the multiannual amplitude to runoff in the summer half-year was analogous to that in 
farmed basins, albeit with the reaction to an increase in precipitation (in the overall context of the period of dry years) coming in the same year where forest was present, as opposed to with a year's delay in agricultural areas. By the end of the analysed dry period, both agricultural and forest basins with a mean level of the ground water table beneath the surface of $h_{\mathrm{zw}}<2.5 \mathrm{~m}$ had runoff around $50 \%$ lower than forest basins with $\mathrm{h}_{\mathrm{zw}}>3.0 \mathrm{~m}$. Differences in the alimentation of drainage basins by outflow can be viewed as a reaction to precipitation manifested by groundwater existing at shallow depths (Gutry-Korycka 1998). As Dębski (1951) noted, the threshold sum for an impact on runoff/outflow in Polish conditions is an annual precipitation total of around $600 \mathrm{~mm}$. Up to this value, precipitation first and foremost acts to raise levels of groundwater, while beyond it the influence declines in favour of increased reinforcement of runoff/outflow (Fig. 4).

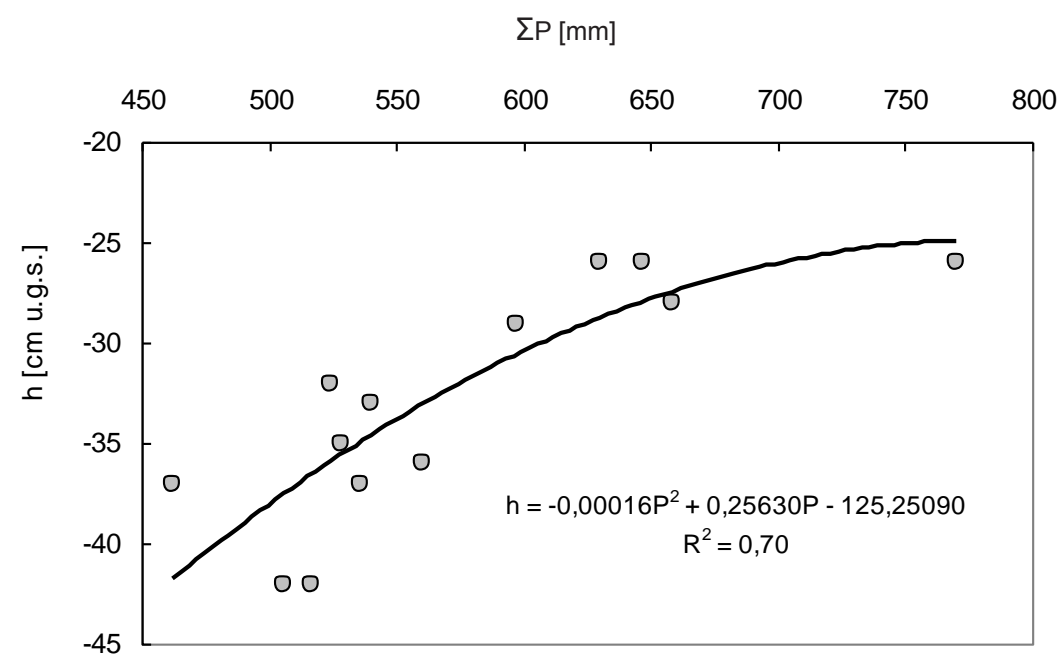

Figure 4. Influence of annual years precipitation totals ( $\mathrm{P}$ in $\mathrm{mm}$ ) on the state of ground waters ( $\mathrm{h}$ in $\mathrm{cm}$ u.g.s. - below the land surface) in marshy and wet coniferous forest habitats of the Polish Lowland

\section{THE INFLUENCE OF HABITAT CONDITIONS ON INCREMENTS IN THE BREAST-HEIGHT DIAMETERS OF TREES}

The dynamic to the growth of tree stands in wet habitats is most influenced by the way in which the water table is shaped. Thus, if the conditions of functioning of naturally-valuable forest ecosystems in wet and swampy habitats are to be improved, it is of crucial importance that a stabilised situation be maintained when it comes to groundwater. Changes in the depth at which groundwater is located are associated with both precipitation totals and the intensity of evapotranspiration, the latter in 
turn depending on biomass production (Suliński 1993, Tyszka 2008). This is made clear by results for breast-height-diameter increases in Scots pines growing in marshy habitats drained to varying extents. The mean depth of water below the surface in the summer half-year that is seen to be optimal for the growth of pines in natural or drained hydrogenic soils is $20 \mathrm{~cm}$ (Fig. 5). Where the water table recedes to greater depths the consequence can even be a halving of increments in girth.

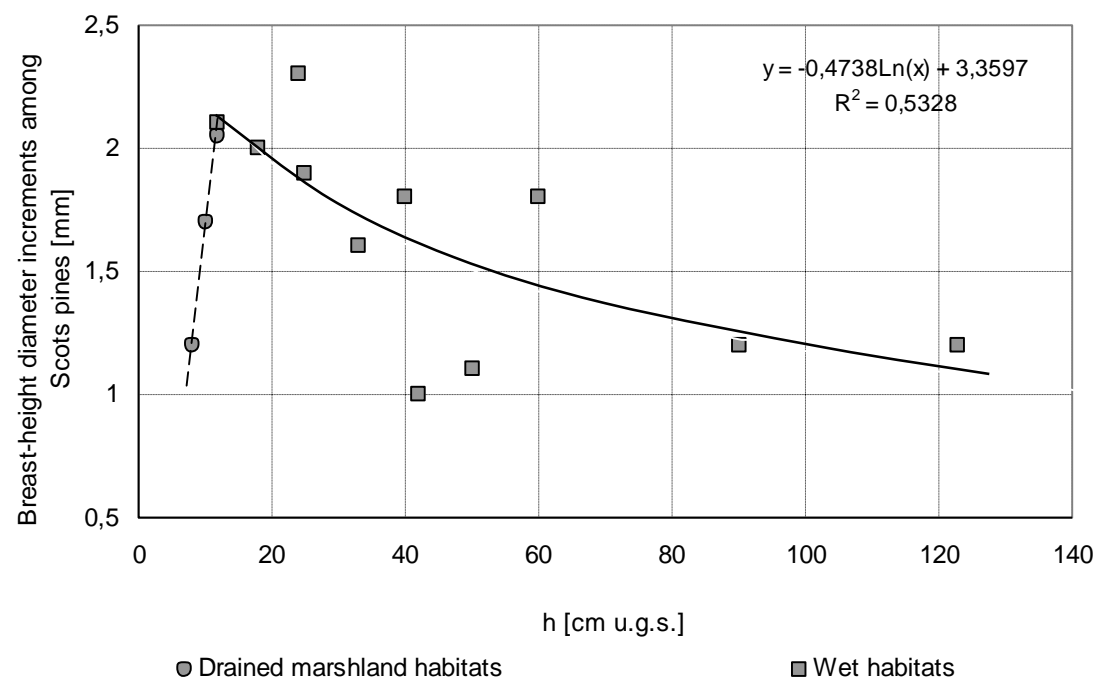

Figure 5. Influence of position of the water table ( $\mathrm{h}$ in $\mathrm{cm}$ u.g.s. - below the land surface) in the summer half-year on breast-height diameter increment $(\mathrm{mm})$ among pines in marshy and wet coniferous forest habitats

In mineral soils, receding groundwater is again seen to have an impact on girth increments in Scots pines that is unfavourable overall. However, the course this relationship assumes is found to be conditioned by habitat, with the optimal circumstance being 80 or $135 \mathrm{~cm}$ below the surface in the cases of wet and fresh habitats respectively (Fig. 6).

A negative influence on increases in breast-height diameter was also found with more major fluctuations in the water table. The latter were described using differences in the position of the surface of groundwater in the summer half-year, between the long-term mean value and mean values relating to annual maxima. The negative influence of the phenomenon on wet habitats is made clear by a near-halving of annual radial increments in pines where there is a $20 \mathrm{~cm}$ increase in the amplitude characterising the water table through given growing seasons (Fig. 7). This reflects the distribution of the rhizosphere, which - in the case of mature stands - only adjusts with great difficulty to more rapid changes in the level of groundwater. 


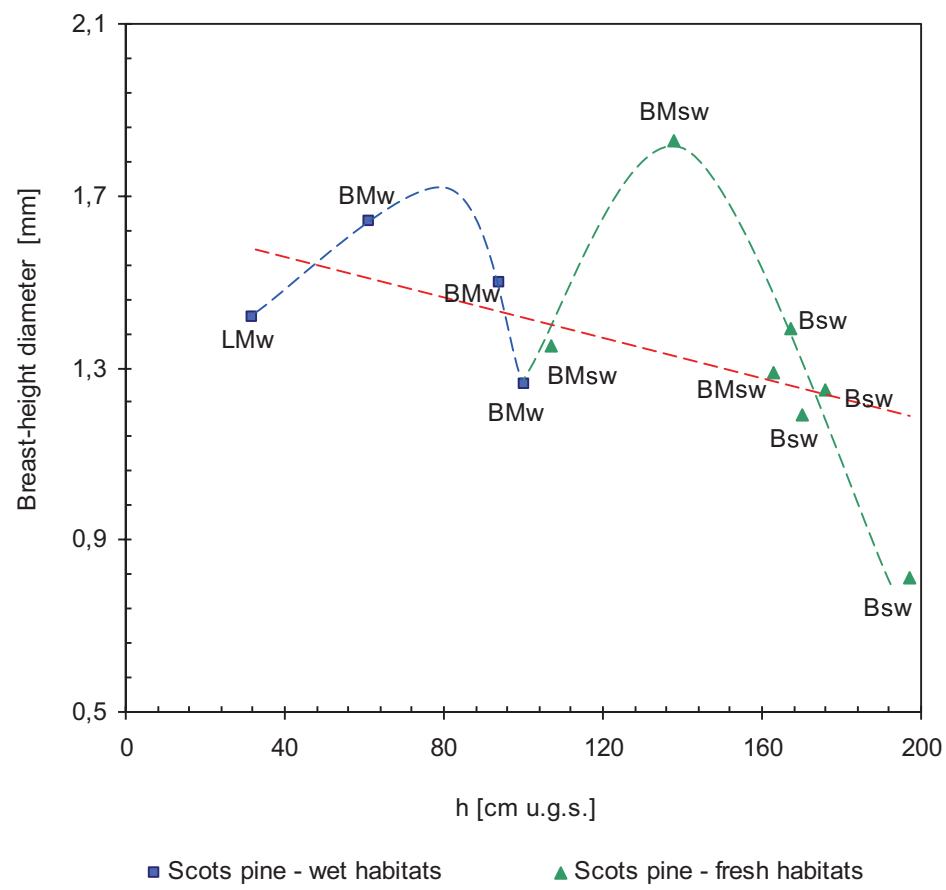

Figure 6. Influence of position of the water table (h in $\mathrm{cm}$ u.g.s.) on breast-height diameter increment among pines in wet and fresh habitats of the Janowskie Forests, on the basis of research carried out in the 1970-2012 period

Forest habitats: mixed fresh coniferous (BMsw), fresh coniferous (Bsw), mixed moist coniferous (BMw), mixed moist deciduous $\mathrm{LMw}$ )

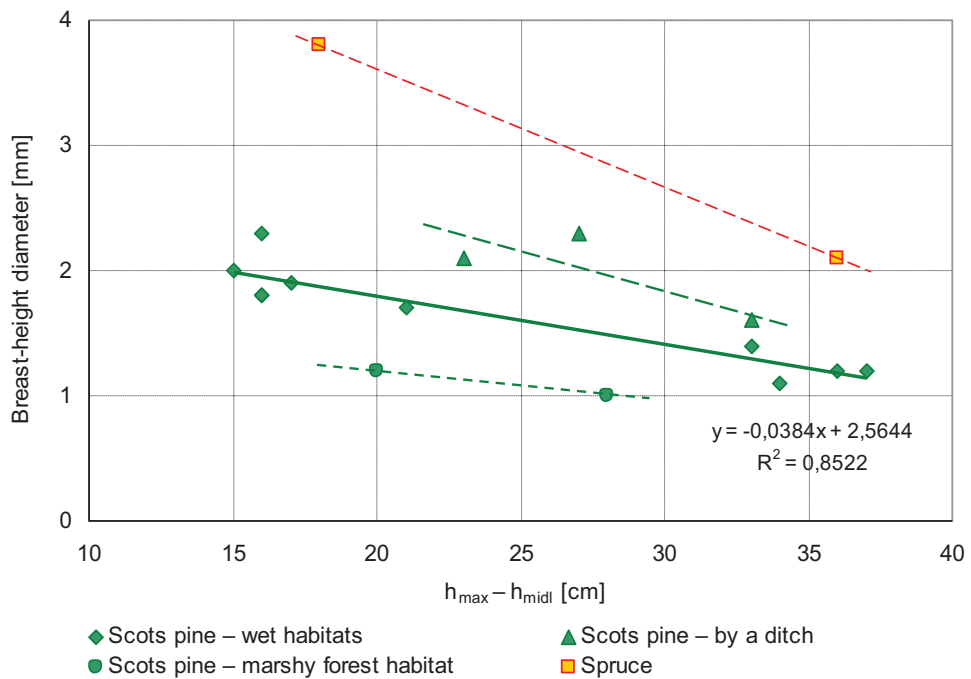

Figure 7. Influence of amplitude of the water table in the summer half-year $\left(\Delta \mathrm{h}=\mathrm{h}_{\max }-\mathrm{h}_{\text {midl }}\right)$ on radial increments in Scots pine and Norway spruce in different habitats 
Using measurements for 10-year breast-height-diameter increments in Scots pine and Norway spruce it proved possible to devise ongoing forecasts for growth rates in these species (Tab. 2).

Table 2. Forecast breast-height diameters $(\mathrm{T}-\mathrm{cm})$ of 100-year-old Scots pines and Norway spruces on the basis of the results of research on increments in four successive decades

\begin{tabular}{|c|c|c|c|c|}
\hline Decades & $\begin{array}{c}\text { Precipitation totals } \\
\text { (May-October) } \\
\mathbf{P}(\mathbf{m m})\end{array}$ & $\begin{array}{c}\text { Air temperature } \\
\text { (May-October) } \\
\mathbf{t}\left({ }^{\circ} \mathbf{C}\right)\end{array}$ & $\begin{array}{c}\text { Scots pine } \\
\text { T } \mathbf{( c m})\end{array}$ & $\begin{array}{c}\text { Norway spruce } \\
\text { T (cm) }\end{array}$ \\
\hline $1972-1981$ & 442 & 13.7 & 45.7 & 42.1 \\
\hline $1982-1991$ & 356 & 14.1 & 47.6 & 45.6 \\
\hline $1992-2001$ & 399 & 14.5 & 43.6 & 48.1 \\
\hline $2002-2011$ & 418 & 14.4 & 44.1 & 49.5 \\
\hline
\end{tabular}

In particular 10-year periods, increments began to be affected where differences in mean air temperature reached $0.8^{\circ} \mathrm{C}$, and where precipitation totals differed by $86 \mathrm{~mm}$ of more (as set against a maximal difference in year-to-year precipitation equalling $400 \mathrm{~mm}$ ). The best progress with growth increments in pine - equating to an average of $47.6 \mathrm{~cm}$ per 100 years - characterised the period 1982-1991, during which the presence of reserves of groundwater built up in previous years coincided with high air temperatures and increased insolation. In turn, in the period of dry and warm years extending from 1992 to 2001 , the corresponding figure equated to $43.6 \mathrm{~cm} / 100$ years, while in the last decade (in which there was marked variability of water conditions in habitats in association with both the extremely dry years 2001 and 2003, and the record precipitation totals of 2010), the forecast girth increments were at the equivalent of $44.1 \mathrm{~cm}$ per 100 years. Monitoring of the accuracy of forecasts for growth rates of trees should be carried out to the age of felling trees. The decade periods of the relationship's analysis between the growth of trees on the thickness and variability of weather parameters are conditional upon a meaningful assessment of the increase in breast-height diameter (DBH). A similar analysis was conducted for spruce trees, albeit with a less representative measurement group. This pointed to persisting elevation of forecast growth increments, which did materialise in decades with near-normal precipitation totals and a relatively high air temperature. However, variable weather conditions in habitats in which the water table receded overall gave rise to a weakening of spruce trees in many areas.

\section{THE INFLUENCE OF THE TEMPORAL BREAKDOWN OF PRECIPITATION ON THE CONDITION OF TREE STANDS}

Overall, the last two decades have brought an improvement in the condition of tree stands, inter alia attributable to a healthier environment with reduced impacts of acid rain. In the circumstances of an increasing demand for water manifested by forests (itself the result of increased air temperature and greater stand productivity), 
as well as precipitation totals that have changed little, the factor determining the state of water resources in a forest is (increasing) evapotranspiration (Tyszka 2008). Since leaf-buds are generated in autumn, only to develop the following year, the influence of precipitation totals on the condition and state of health of stands sometimes operates via a two-year cycle (Mykhayliv 2010). This regularity is confirmed in assessments of the average level of crown defoliation carried out annually throughout Poland (Wawrzoniak 2013). The state of health of forest viewed annually tends to display several-year fluctuations (Fig. 8), in line with breakdowns of figures for precipitation in the summer half-year, and in the face of trends that are favourable overall.
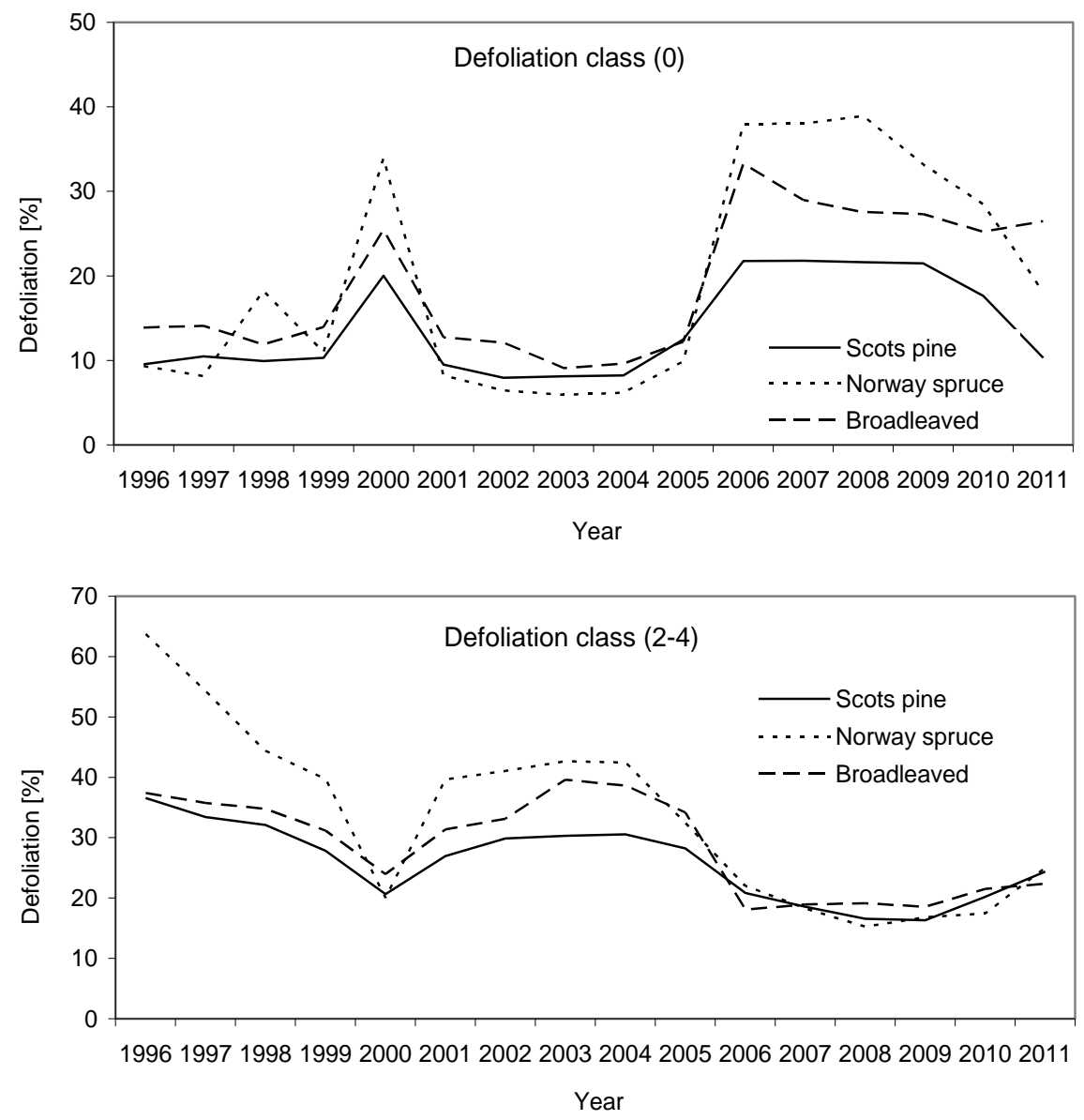

Figure 8. 1996-2011 course for degree of crown defoliation among selected tree species, with a distinction drawn between healthy stands (defoliation class 0 ) and stands with moderately- or severely-damaged or dead crowns (defoliation classes 2-4), on the basis of data in monitoring research (Wawrzoniak 2013) 
It is possible to identify three c. 5-year-long periods of variability:

- the years 1996-2000, with high if declining precipitation totals and improving condition of trees,

- the years 2001-2005, with low precipitation totals and only a small share of stands in the heathy 0 defoliation class,

- the years 2006-2011, with increasing precipitation and improving conditions of stands, as is indicated by an increase in the proportion of stands assigned 0 defoliation, as compared with stands in damage classes 2-4.

Breakthrough years for the condition of forests proved to be those with higher growing-season precipitation totals, following on from successive dry years. The key years of this kind were 1996, 2001 and 2006, after each of which there was a rise in the level of groundwater. In turn, the very wet year 2010 was followed by a worsening in the state of health of conifers. Where hydro-climatic conditions are similar overall, the condition stands manifest is species-related. The most distinct reaction to differences in precipitation totals during the (April-September) growing season was that of spruce stands. The level of assignment of these stands to defoliation classes 2-4 fell from $63 \%$ in 1996 to just $16 \%$ in 2008, while the years 2004-2006 brought a more than $30 \%$ increase in the share of healthy stands manifesting defoliation class 0 . Variability to the levels of defoliation among broadleaved trees and Scots pines was found to be similar (from around $10 \%$ in class 0 to c. $40 \%$ in classes $2-4$ ). The most favourable external conditions for all the species of tree considered were experienced in the aftermath of the wet year 2006, the effects persisting through until 2009.

As part of the search for the optimal precipitation conditions favouring reduced defoliation, an attempt was made to assess the relationship between mean precipitation totals in two successive growing seasons and the shares of trees assigned to defoliation classes 2-4, with the cyclicity to changes also being taken into account (Fig. 9).

There is seen to be periodic variability to the impact of precipitation on defoliation. Wet years coinciding with the century's end, and following on from a long period in which there was a prevalence of dry years, were associated with weakening of most stands, albeit with this problem less severe in years with growing-season precipitation totals of around $380 \mathrm{~mm}$. In turn, following on from two consecutive dry growing seasons, the year 2003 brought a worsening in the condition of stands, followed by an improvement after 2006 when precipitation totals once again passed the $380 \mathrm{~mm}$ level. From 2007 on, high rainfall totals dominated, with years other than 2010 not characterised by any more major damage to foliage in the tree species analysed. Limited defoliation corresponded with enhanced stand evapotranspiration, especially in the circumstances of average two-year precipitation totals, with each departure of precipitation totals from average levels giving rise to increased defoliation. The most limited threat of the condition of stands being impaired was present where precipitation totals in the growing season were of $384 \mathrm{~mm}$ (in the case of spruce), or around $375 \mathrm{~mm}$ in the cases of Scots pine and broadleaved trees. 


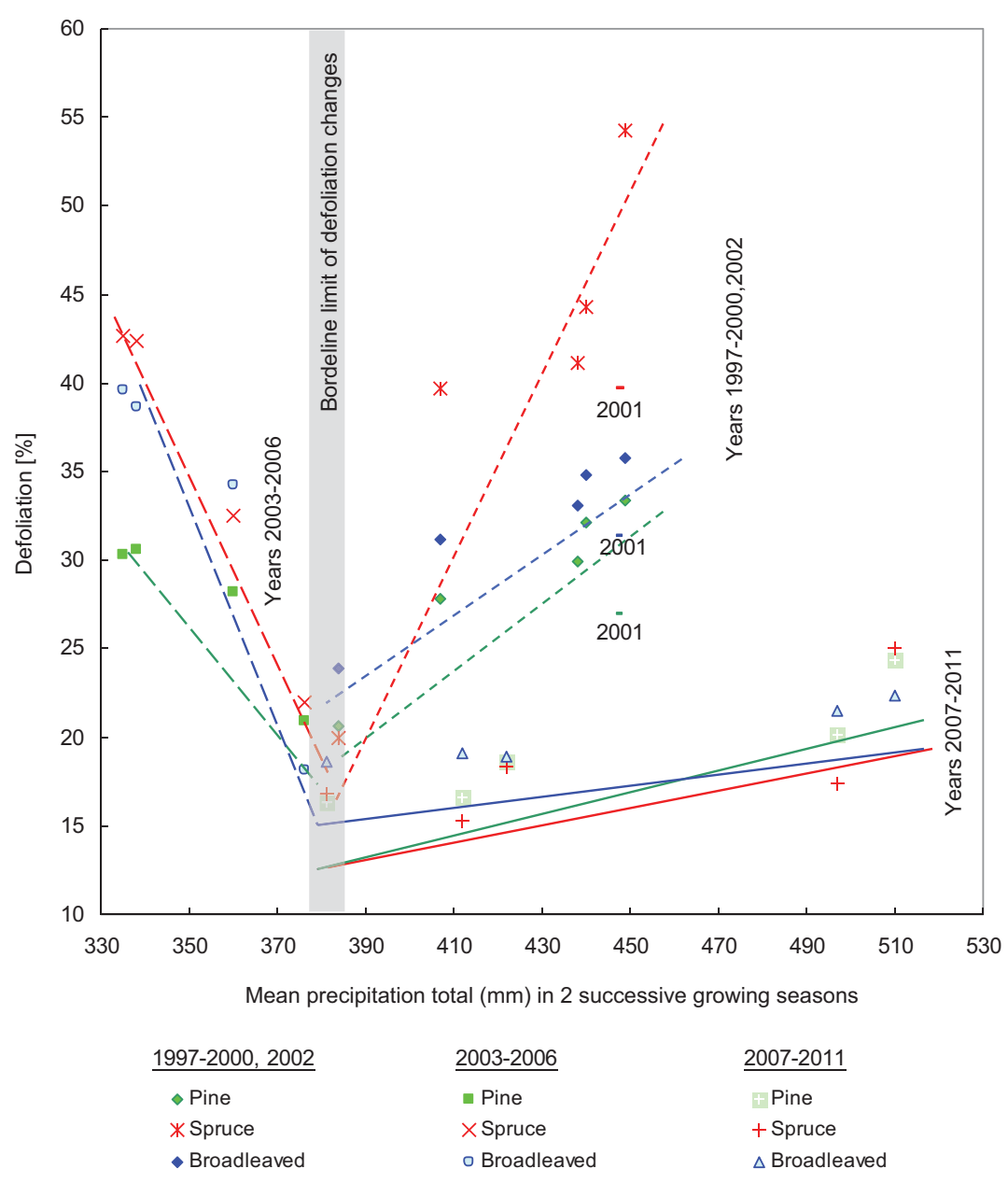

Figure 9. Influence of average precipitation totals in two-year growing seasons on the shares of trees of different species in defoliation classes 2-4

A subsequent analysis then concerned the annual scope to changes in the share of highly-weakened trees, in relation to departures of precipitation totals from an annual mean of $\mathrm{P}_{\mathrm{n}}=614 \mathrm{~mm}$ (Fig. 10).

In the cases of spruce and the broadleaved trees, the reaction to changed precipitation totals resembled that described for the average figure from successive two-year periods of growing-season weather (excluding years in which conditions were extreme). The shares of damaged trees were lowest in years with c. $590 \mathrm{~mm}$ of precipitation (in the case of spruces) or 570 (for broadleaved trees). Only among Scots pines was it possible to note somewhat worse defoliation with increased precipitation totals across the range $500-800 \mathrm{~mm}$. 

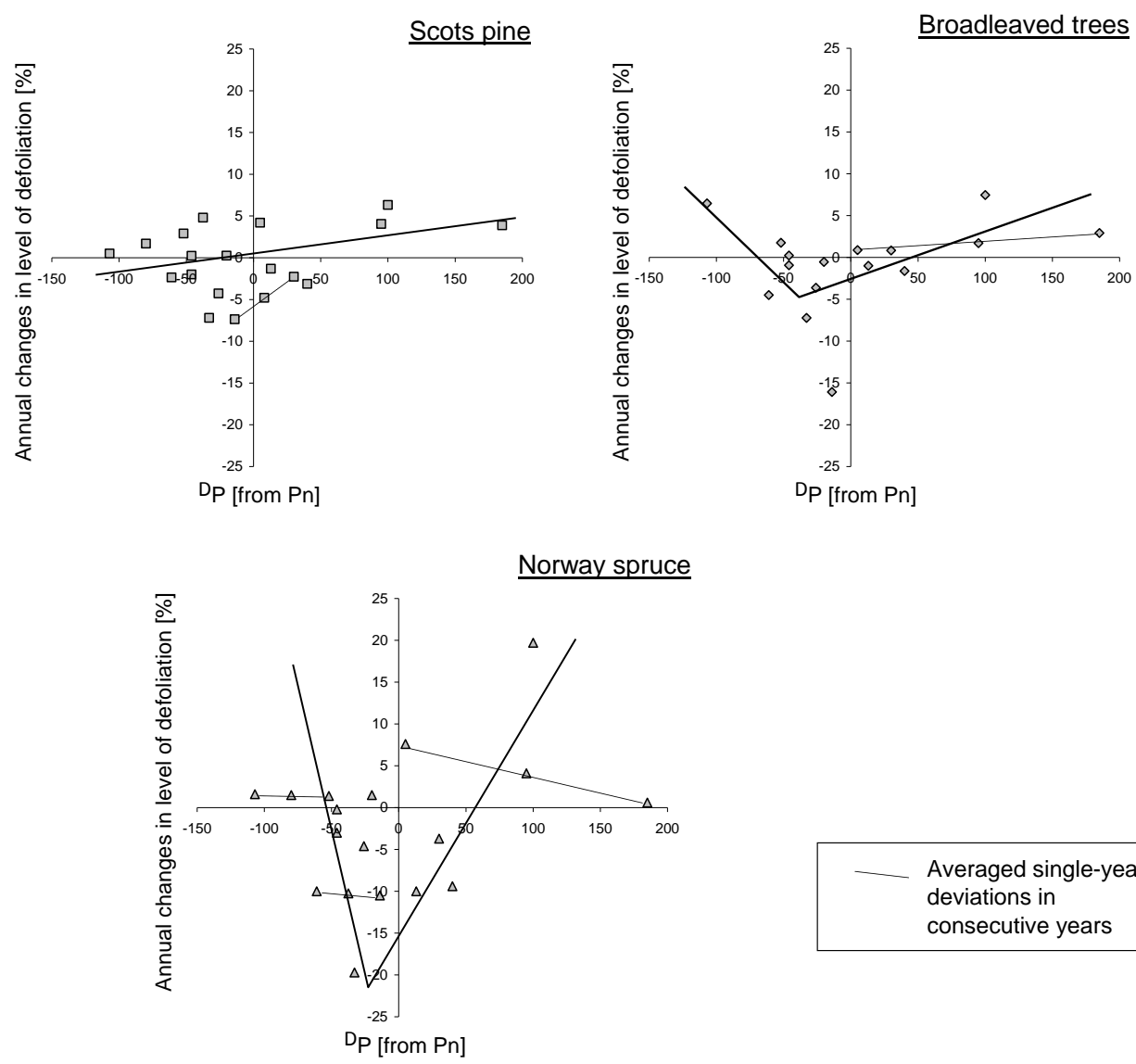

Averaged single-year deviations in consecutive years

Figure 10. Variability to degree of crown defoliation in classes $2-4$ among selected tree species, with account taken of the influence of different annual precipitation totals $\left(\mathrm{P}_{\mathrm{n}}-\mathrm{P}_{\text {midl }}\right)$ across the Polish Lowland

Broadleaved stands casting their leaves annually reacted at once to variability in precipitation. In contrast, conifers (most of all spruces) manifested a two-year rhythm where defoliation was concerned. A worsening of the condition of stands in response to changes in precipitation was mainly noted in years where totals were extremely low, in the face of year-on-year changes in habitat humidity.

\section{DISCUSSION OF RESULTS}

As research done to date makes clear, where courses for air temperature are stable, forest as a natural factor both regulating water cycling and consuming water shapes resources in relation to the overall amount of precipitation, as well as its distribution across 
the year. A relationship of this kind was first determined by Dębski (1951). The research results referred to above make it clear that the course to forest-water relations depends, not only on hydroclimatic conditioning (Baker 1982), but also on natural conditioning reflecting the state trees are in. By definition, a stand's needs for water are met in normal years, while the emergence of weather anomalies and extreme climatic phenomena may disrupt the functioning of forest ecosystems, in this way exerting an indirect impact on the state of water resources. These are linked with a phase of ongoing climatic warming and long-term trends characterising climate change (Tyszka, Stolarek 2013).

In recent years forest has been playing an ever-greater role as a factor stabilising change that climate anomalies would otherwise usher in. Views on the role forest can play in limiting climate change are dominated by awareness of a capacity to sequester carbon very dependent on management methods (Schwerk, Szyszko 2007, Rykowski 1999, 2005, 2008). Such considerations have proceeded on the assumption that increased air temperature reflect increased emissions of carbon dioxide. However, insufficient account has been taken of the role of environmental factors, above all changes in concentrations of water vapour, the cyclical activity characterising solar radiation, emissions of volcanic ash and many others. Nevertheless, a regularity whereby each past increase in air temperature has been associated with an increased content of carbon dioxide in the atmosphere can be noted (Jaworowski 2010).

Such a phenomenon was even present in natural conditions, but can now only be intensified by economic activity. As an antidote to the social, natural and economic impacts exerted by rising air temperature, foresters are seeking to take advantage of enhanced processes of photosynthesis and the accumulation of carbon in wood, litter and the soil. However, the efforts to consider this issue have not so far taken enough account of a regularity long known about, which provides that elevated air temperature and concentrations of carbon dioxide $\left(\mathrm{CO}_{2}\right)$ and nitrous oxide $\left(\mathrm{NO}_{3}\right)$ give rise to greater forest productivity, but also to increased demand for water that can only become more acute where growing-season deficits in precipitation arise. In such circumstances the photosynthesis responsible for increases in biomass takes place with $\mathrm{CO}_{2}$ in excess and $\mathrm{H}_{2} \mathrm{O}$ in deficit. The main element limiting an increase in biomass (in the face of the permanent occurrence of dry periods in the summer half-year) is then water deficit, as the results of research in the recent period of rapidly-progressing environmental change make clear (Tyszka 2008; Tyszka, Stolarek 2013).

A large amount of evaporation leads to a cooling of the air on warm days and a raising of air temperature on cool days. This impact of forest on microclimate involving a reduction of amplitudes in air temperature has been known for a long time, and linked up with increased intensity of exchange between forest and the atmosphere (Gumiński 1952, Tomanek 1954, Aussenac 1999). The direct impact of forest on climate depends on the latter's biomass resources and productivity (Tomanek 1954, Aussenac 2000), which in turn depend on habitat humidity (Larcher 1983). Greater biomass growth is associated with enhanced evapotranspiration, which in turn leads to a fall in active-surface temperature. 
The current intensification of water-resource deficits measured in terms of precipitation, the water table and runoff/outflow will inevitably limit opportunities to offset further enhancement of the greenhouse effect, since sequestration of carbon dioxide must inevitably decline. The desiccation of forest habitats in fact has the further effect of accelerating oxidation of organic matter in hydrogenic soils, this promoting the release of further quantities of $\mathrm{CO}_{2}$. Distortions to water relations are thus also of decisive importance to the production- or non-production-related effectiveness of forest-resource management, and may not be overlooked in assessments of the role forest land and tree-stand condition play in limiting the rate of climate change.

There is a wealth of literature comparing habitat humidity with the state of health of trees of different species (i.a. via the degree to which the demand for water is satisfied). The issues considered relate i.a. to the uptake of water to meet trees' physiological needs, as well as evapotranspiration (Aussenac 1978, 1999; Arris, Eagleson 1994; Boczoń 2004). However, measurements made locally cannot represent larger diversified landscapes under forest cover. Rather, knowledge in this sphere can only advance with in-depth study of the water cycle in ecosystems differing in terms of habitat features, age and species structure, with account also taken of ongoing hydro-climatic changes (via model studies). It is thus vital that the scope of relevant research be widened as far as is feasible, with a view to conclusions of more-universal application being arrived at.

Certain indirect conclusions regarding forest's demand for water can nevertheless be drawn by reference to the variability in hydrological conditions set against drainagebasin water balances. A simple and readily-determined indicator with which to assess the state of water resources involves variability of outflow from forest-covered basins, since this points indirectly to the situation as regards alimentation and retention. The known and documented capacities of forest to retain water are of significance, not only to the evening-out of flows, but also to the stimulation of stand productivity that eases the effects of climate change. It is in this light that we must view it as crucial to the real practice of forestry that stands' needs for water are met; as necessary using natural methods to increase retention, or else installations in forests that regulate flow (Pierzgalski et al. 2005, Pierzgalski 2007, Pierzgalski et al. 2012). By these means the change in water relations affecting forest functioning may be limited in scale, with the result that the condition and sustainability of the forest ecosystem is enhanced, stand productivity raised, and more stable climatic conditions assured. In practical terms, the task of foresters should therefore be to take targeted action entailing:

- (in forests enjoying habitat and species protection) - painstaking efforts to ensure stability of conditions as regards water, since preservation of biodiversity will be assured if the influences of anthropogenic factors and extreme climatic phenomena are curtailed;

- (in managed forests, above all those assigned a role in protecting both the quantity and quality of available water) - essential work to improve conditions of forest functioning through appropriate management, silviculture and utilisation, as well as resort to technical methods of regulating water relations. 


\section{CONCLUSIONS AND REMARKS}

- Climate change - and especially the attendant extreme meteorological phenomena - may do much to bring about the weakening, dieback of even die off of tree stands. In this regard, the main negative impact arises during (often relatively short) periods arising every few years in which there is a marked deterioration in the situation regarding water resources (as indicated by atmospheric precipitation and the level of groundwater, and as manifested in a destabilisation of river flows). With climatic warming, it is above all the conditions in spruce stands that have deteriorated, with a simultaneous expansion being noted for certain broadleaved species less demanding as regards the supply of water. It is possible that this in fact heralds changes in the boundaries of zones of vegetation and climate as recognised hitherto.

- Each - even minor - departure from the hydrological conditions (i.e. the measured totals and temporal distributions of precipitation, as well as levels of groundwater) that longlived forest ecosystems have become adapted impairs stand condition and productivity, this having further consequences for the non-production functions forests also serve.

- The intensified production of biomass influences the forest topoclimate both directly and indirectly: evapotranspiration and hence precipitation increases, and there is absorption of carbon dioxide that represents sequestration from the carbon cycle operating in nature, and hence an influence that will tend to act to curtail increases in air temperature.

- The assessment of the trends and scope to changes in the major factor determining the condition of stands that water conditions in forest habitat represent requires long-term measurement of basic hydro-climatic parameters. In particular, in the circumstances of the recent period of dynamic variability to weather conditions, far-reaching further coordination of research is crucial to any fuller understanding of how the health of forest in diverse habitats depends on conditions as regards water.

- If there is to be active combating of the negative influences of climate change notably the attendant marked variability in water resources, it will be necessary to take note of forecast changes to determine the necessary scope of adaptive remedial activity in the form of appropriate forestry measures, including as regards water management in forests. 


\section{REFERENCES}

Arris L.L., Eagleson P.S., 1994, A water use model for locating the boreal/deciduous forest ecotone in Eastern North America, Water Resources Research, 30, 1, 109.

Aussenac G., 1978, La sécheresse de 1976: influence des déficits hydriques sur la croissance des arbres forestiers, Biologie et Forêt. Revue Forestiere Francaise, XXX, 2, 103-114.

Aussenac G., 1999, Forests and water: relations between forest ecosystems and water resources, [in:] Sustainable Forest Management: Contribution of Research, IUFRO.

Aussenac G., 2000, Interactions between forest stands and microclimate: Ecophysiologic aspects and consequences for silviculture, Ann. For. Sci., 57, 287-301.

Baker M.B., 1982, Hydrologic Regimes of Forested Areas in the Beaver Creek Watershed, General Technical Report RM-90 U.S.

Boczoń A., 2004, Zużycie wody przez dęby w siedlisku lasu wilgotnego, (Water use by oaks in the habitat of moist decidous forest), Monografie Komitetu Gospodarki Wodnej PAN, 23, pp 123.

Bruchwald A., 1986, Simulation growth model MDI1 for Scots pine, Ann. Warsaw Agricult. Univ. SGGW-AR, For. and Wood Technol., 34, 47-52.

Bruchwald A., Dudzińska T., Dudek A., Michalak K., Wróblewski L., Zasada M., 1999, Model wzrostu dla drzewostanów świerkowych, (Growth model for Norway spruce stands), Sylwan, Sylwan, 1, 19-31.

Byczkowski A., 1996, Hydrologia, (The Hydrology), T. I, SGGW, Warszawa.

Dębski K., 1951, Wptyw lasu na stosunki hydrologiczne, (The impact of forest on the hydrological conditions), Wiadomości Służby Hydrologicznej i Meteorologicznej, 3-4, 57-70.

Gumiński R., 1952, Las, jako czynnik makroklimatyczny, (The forest as a macroclimatic factor), Wiadomości Służby Hydrologicznej i Meteorologicznej, 3, 2.

Gutry-Korycka M., 1998, Dlugookresowe tendencje obiegu wody w zlewni nizinnej Utraty, (Long-term water cycle tendencies in the lowland catchment of Utrata), Acta Geographica Lodzenia, Łódź 74, 49-60.

Hendricks D.W. and V.E. Hansen, 1962, Mechanics of evapo-transpiration, J Irrig Drain. Div., Am. Soc. Civil. Eng., 88 IR-2, 67-82.

Jaworowski Z., 2010, Klimatem rzadzi stońce, (The climate is ruled by the sun), Kosmos, 59, 231-249.

Kędziora A., Ryszkowski L., 1999, Does plant cover structure in rural areas modify climate change effects?, Geographia Polonica, 72, 2, 65-87.

Kosturkiewicz A., Korytkowski M., Stasik R., Szafrański C., 2002, Amplitudy zmian poziomu wody gruntowej w glebach siedlisk leśnych, jako wskaźnik ich zdolności retencyjnych, (The amplitude to ground water levels in the soils of different forest habitats as an indicative measure of habitats retention capacity), Roczniki A.R. w Poznaniu, CCCXXXVIII, 22, 55-64.

Larcher W., 1983, Physiological Plant Ecology, corrected printing of the $2^{\text {nd }}$ Edition, translated by M.A. Biederman-Thorson, New York.

Manual on methods and criteria for harmonized sampling, assessment, monitoring and analysis of the effects of air pollution on forest, UNECE, ICP Forest Programme Co- ordinating Center, 2010, Hamburg, ISBN:978-3-926301-03-1. 
Mykhayliv O., 2010, Wpływ czynników meteorologicznych na wystepowanie chorób infekcyjnych $w$ lasach, (The impact of meteorological factors on the occurence of infectious diseases in the forests), Forest Research Institute, Sękocin Stary.

Pierzgalski E., Tyszka J., 2005, Water outflow during drought years in watersheds with various forest cover, Annals of Warsaw Agricultural University, 36, 21-28.

Pierzgalski E., Ciepielowski A., Tyszka J., Wiśniewski S., 2005, The rules of water management in forests, [in]: Protection of soil and water resources in forestry areas, Forest Research Institute, Warsaw, 163-181.

Pierzgalski E., 2007, Potrzeby, kierunki i metody retencjonowania wód na obszarach zarzadzanych przez Państwowe Gospodarstwo Leśne, (Needs, directions and methods of water retentioning on the territory managed by the State Forest Husbandary), Forest Research Institute, Sękocin Stary.

Pierzgalski E., Tyszka J., Janek M., Stolarek A., Wróbel M., Bruchwald A., Dmyterko E., Szendera M., Klos M., 2012, Ocena wpływu obiektów małej retencji w lasach nizinnych na zmiany $w$ ekosystemach leśnych i ograniczenie zagrożenia susza, (Assesment of the impact of small retention objects in lowland forests on changes in forest ecosystems and mitigation of drought threat), Forest Research Institute, Sękocin Stary.

Prończuk J., 1982, Podstawy Ekologii Rolniczej, (Framework of the agricultural ecology), PWN, Warszawa, 348.

Rykowski K., 1999, Assessment of the importance of forests to reduce the global change (counteracting and mitigation of the impacts of $G H G$ ), Geographica Polonica, 72, 2, $27-44$.

Rykowski K., 2005, O wplywie zmian klimatycznych na lasy i leśnictwo, (About the influence of climate changes on forests and forestry), Biblioteka Leśniczego, 244, Wyd. Świat, Warszawa.

Rykowski K. (ed.), 2008, Climate change, Forest, Forestry Relationships, Centrum Informacyjne Lasów Państwowych, Warszawa, pp 70.

Schwerk A., Szyszko J. (eds), 2007, Landscape architecture and spatial planning as the basic element in the protection of native species - planning of space in the water catchment area, Warsaw Agricultural University Press, Warsaw, pp 171.

Somorowska U., 2009, Wzrost zagrożenia susza hydrologiczna w różnych regionach geograficznych Polski w XX wieku, (Increase in the hydrological drought risk in different geographical regions of Poland in the 20th century), Prace i Studia Geograficzne, 43, 97-114.

Suliński J., 1990, Wpływ wieku drzewostanów na składowe obiegu wody w Puszczy Niepołomickiej, (Impact of stands age on components of the water cycle in Puszcza Niepołomicka), Gospodarka Wodna, 5, 108-110.

Suliński J., 1993, Modelowanie bilansu wodnego $w$ wymianie między atmosfera, drzewostanem i gruntem przy użyciu kryteriów ekologicznych, (Water balance modelling in the exchange between the atmosphere, tree stand and the ground by means of ecological criteria), Zeszyty Naukowe Akademii Rolniczej w Krakowie, 179, 1-10.

Tomanek J., 1954, Klimatyczne $i$ hydrologiczne znaczenie lasów (Climatic and hydrological importance of forests), Gospodarka Wodna, 12, 461-465. 
Tyszka J., 2006, Ksztaltowanie się zasobów wodnych lasu w zmieniajacych się warunkach klimatycznych, (Forming of water resources in the forest under changing climatic conditions), [in]: Quo vadis, forestry?, Sierota Z. (ed.), Forest Research Institute, Sękocin Stary, 440-448. Tyszka J., 2008, Hydrological functions of forests in small lowland catchments, Papers of the Forest Research Institute, Sękocin Stary, pp. 215.

Tyszka J., Stolarek A., 2013, Changes in runoff as an indicative measure of water retention status in Białowieża Primeval Forest, Folia Forestalia Polonica, series A, 55, 2, 72-88.

Wawrzoniak J., 2013, Stan uszkodzeń lasów w Polsce na podstawie badań monitoringowych,

Roczniki 1996-2012, (Forest damage state in Poland on the basis of monitoring research, Issues 1996-2012), Forest Research Institute, Sękocin Stary. 